\title{
Energy, Sustainability and Society is celebrating two years of successful open-access publication
}

\author{
Michael Narodoslawsky ${ }^{1}$ and Dagmar Fiedler ${ }^{2^{*}}$
}

Dear Reader,

At the end of this year, our journal will be celebrating its second anniversary of appearance. Looking back on 2 years of successful open-access publication, the secret of our journal may not exclusively be explained by its new and modern form of publication but also by its broad and timely scope as an interdisciplinary forum for research, development and implementation of sustainable energy systems.

The last 2 years has arguably been the most dynamic period in the relation between energy and society since the invention of the steam engine. It has seen the catastrophe in Fukushima, reiterating the environmental and societal risks of our current energy system. The recent report of the Intergovernmental Panel on Climate Change (IPCC) has clearly indicated an accelerating climate change as a consequence of still-rising greenhouse gas emissions. Finally, we are witnessing a dramatic reconfiguration of electricity systems, with wind power and photovoltaic electricity increasingly becoming game changers for markets and infrastructure.

Energy, Sustainability and Society covers complex topics ranging from scientific research to both innovative approaches for technology implementation and the analysis of economic, social and environmental impacts of sustainable energy systems. Topics such as (1) featuring sustainable, economically feasible as well as environmentally and socially compatible energy supply for human society, (2) considering the emerging environmental, social and economic conflicts resulting from the introduction of renewable energy technologies and (3) presenting new holistic system solutions for the development of novel future energy options are the focus of Energy, Sustainability and Society. Our journal strives to publish early scientific opinions on issues which are just emerging and require crosscutting and out-of-the

\footnotetext{
* Correspondence: dagmarfiedler@ufz.de

${ }^{2}$ Helmholtz-Zentrum für Umweltforschung GmbH - UFZ, Permoserstraße 15, 04318 Leipzig, Germany

Full list of author information is available at the end of the article
}

box thinking. The mission of our journal is to provide a cutting-edge forum for the discourse between natural, social and political scientists and engineers, as well as experts from industry and the public sector, who drive the innovation of sustainable energy systems.

The journal publishes articles which include concepts for discovering novel energy sources, energy mixes and energy systems requiring a large variety of technological solutions, sophisticated computer simulations, novel laboratory technologies, large-scale research facilities, as well as scenario development and national and international networks.

A journal that encompasses such a novel field which is regarded as being as dynamic as sustainable energy systems also needs to be quick in processing contributions from our authors. It is quite evident that Energy, Sustainability and Society, which appears on SpringerOpen, Springer's internet platform, has many advantages in this respect.

The challenges and expectations at the interface of science, environment, technology and society reflect both the research field of the Helmholtz Association and the distinct focus of the European Sustainable Energy Innovation Alliance (eseia). Therefore, scientists from the Helmholtz Association and the eseia are partners in the edition of our multidisciplinary, international openaccess journal which is freely available online to anyone, anywhere.

True to its mission, Energy, Sustainability and Society will continue to provide an interdisciplinary platform for the exchange of ground-breaking ideas regarding the energy turnaround as well as the change in the resource basis of human society towards renewable sources of energy and raw materials. Our journal will also continue to follow the ongoing systemic change of energy systems in different regions and will vigorously participate in the ever stronger discourse on how to transform urban settlements into smart cities. Therefore, Energy, Sustainability and Society will invite contributions dealing with the dramatic challenges posed by sustainable 
energy systems to our built environment as well as a critical analysis of existing and innovative energy systems according to their impacts on our economic, social and ecological life cycle. Apart from new societal and economic models for implementing sustainable energy systems, the journal will focus on innovative technological system solutions for bio-refineries, carbon capture, reuse systems and many further engineering approaches which are of great importance to making our energy supply sustainable, safe and profitable. In short, our journal aims to drive the field forward and to seek the ideas that will shape our world in the twenty-first century.

Based on these well-defined concepts and clear aims, Energy, Sustainability and Society has developed very well and attracted worldwide interest. It has had a steadily increasing supply of interesting papers submitted to our platform from more than 15 countries over the last 2 years.

From time to time, the journal publishes special topical or conference issues that concentrate on specific areas. As an example, one of these three article collections was dedicated to the Microbiology of Sustainable Biogas Production (with Sabine Kleinsteuber as the Guest Editor). At this time, two further article collections of invited papers providing an overview of the status quo and latest advances in a special area of our interdisciplinary scope have been prepared on our platform, and two others are planned to be released in early 2014 .

We will take this occasion not to forget to thank our authors for their sustained confidence and our valued referees and the staff at both Springer (Monika Bechtold and Paul Roos) and SpringerOpen (Lea Aludino, Samuel Beattie, Jesun Somoza and Thomas Marsh), as well as the members of the Editorial and Advisory Board for their tremendous work and generous help in the edition of Energy, Sustainability and Society.

Dagmar Fiedler would also like to acknowledge the great help and encouragement she has received and continues to receive from the Helmholtz Centre for Environmental Research GmbH - UFZ (Leipzig). Michael Narodoslawsky would like to thank the eseia team for its outstanding support and for the invaluable expertise it provides to this journal.

And last but not least, we would cordially invite you to be among the many authors who contribute to Energy, Sustainability and Society. You are asked to follow the instructions at http://www.energsustainsoc.com/authors/ instructions.

Finally, we would like to wish the journal every success in its further development and a steadily increasing acceptance among the scientific community.

Sincerely yours,

Michael Narodoslawsky \& Dagmar Fiedler

(Editor-in-chief and Managing Editor)
Author details

${ }^{1}$ Technische Universität Graz, Inffeldgasse 13/3, 8010 Graz, Austria.

${ }^{2}$ Helmholtz-Zentrum für Umweltforschung GmbH - UFZ, Permoserstraße 15, 04318 Leipzig, Germany.

Received: 15 October 2013 Accepted: 15 October 2013 Published: 25 October 2013

doi:10.1186/2192-0567-3-21

Cite this article as: Narodoslawsky and Fiedler: Energy, Sustainability and

Society is celebrating two years of successful open-access publication.

Energy, Sustainability and Society 2013 3:21.

\section{Submit your manuscript to a SpringerOpen ${ }^{\circ}$ journal and benefit from:}

- Convenient online submission

- Rigorous peer review

- Immediate publication on acceptance

- Open access: articles freely available online

- High visibility within the field

- Retaining the copyright to your article

Submit your next manuscript at $>$ springeropen.com 